\title{
Profil Penggunaan Obat Batuk Pilek bebas pada Pasien Anak di bawah umur 6 Tahun
}

\author{
Soepardi Soedibyo, Arie Yulianto, Wardhana \\ Departemen Ilmu Kesehatan Anak Fakultas Kedokteran Universitas Indonesia/RS Dr. Cipto Mangun \\ Kusumo, Jakarta
}

\begin{abstract}
Latar belakang. Obat batuk pilek over the counter (OTC) banyak digunakan secara luas oleh orang tua untuk mengatasi keluhan batuk pilek pada anak. American Academy of Pediatrics (AAP) merekomendasikan untuk tidak menggunakan obat batuk pilek yang dijual bebas pada anak usia di bawah 6 tahun oleh karena belum sepenuhnya teruji efektivitasnya pada anak, bahkan terdapat risiko efek samping berbahaya.

Tujuan. Mengetahui profil penggunaan obat batuk pilek OTC oleh orang tua pada anak usia di bawah 6 tahun di Puskesmas Kelurahan Pegangsaan, Jakarta.

Metode. Penelitian deskriptif (survei) dengan teknik wawancara menggunakan kuesioner pada semua orang tua pasien yang membawa anak sakit berumur di bawah 6 tahun di Puskesmas kelurahan Pegangsaan dalam periode 17 Oktober 2011 sampai 04 November 2011. Pengambilan sampel dilakukan secara konsekutif. Hasil. Didapatkan 106 responden penelitian, 82,1\% orang tua memberikan obat batuk pilek OTC dengan alasan supaya anak cepat sembuh (47,2\%). Kandungan obat batuk pilek OTC yang digunakan adalah klorfeniramin maleat $(58,8 \%)$, parasetamol (56,5\%), gliceryl guaicolate $(50,6 \%)$, pseudoefedrin $(28,2 \%)$, dextromethorphan $(22,4 \%)$ dan bromhexine $(9,4 \%)$. Efek samping obat dirasakan pada $31 \%$ responden, dan gejala terbanyak adalah mengantuk $(85 \%)$.

Kesimpulan. Sebagian besar orang tua memberikan obat batuk pilek OTC apabila anaknya sakit. Komposisi kombinasi obat OTC yang banyak digunakan adalah klorfeniramin maleat, parasetamol, gliceryl guaicolate, pseudoefedrin, dextromethorphan dan bromhexine. Efek samping mengantuk yang terbanyak dirasakan oleh subjek. Sari Pediatri 2013;14(6):398-404.
\end{abstract}

Kata kunci: obat batuk pilek, OTC

atuk pilek merupakan penyakit yang menyerang baik anak maupun dewasa. Pada anak, batuk pilek banyak terjadi pada usia di bawah 6 tahun. Rata-rata setiap anak

\footnotetext{
Alamat korespondensi:

Prof. Dr. Soepardi Soedibyo, Sp.A(K). Pediatri Rawat Jalan Dep. Ilmu Kesehatan Anak FKUI. Divisi Nutrisi dan Metabolik, Departemen Ilmu Kesehatan Anak FKUI - RSCM. Jl. Salemba no. 6, Jakarta 10430. Telp. (021) 3915179. Fax: (021) 3907743, Wardhana: 085216302030
}

mengalami 6 hingga 8 kali keluhan setiap tahunnya. Batuk pilek sebagian besar disebabkan oleh rhinovirus, adenovirus, virus influenza, enterovirus, RSV, dan coronavirus. ${ }^{1}$

Obat over the counter (OTC), atau obat yang dijual bebas untuk keluhan batuk pilek, banyak digunakan oleh orang tua untuk mengatasi keluhan batuk pilek, banyak tersedia untuk anak dengan berbagai macam kombinasi. Obat batuk pilek yang beredar tersebut, 
umumnya memiliki kandungan antihistamin, dekongestan, antitusif, ekspektoran, dan analgesik/antipiretik. ${ }^{1}$ Mary $\mathrm{dkk}^{2}$ pada studi postmortem bayi usia 17 hari hingga 10 bulan di Arizona, didapatkan sepuluh kematian bayi diidentifikasi berkaitan dengan penggunaan obat batuk pilek yang mengandung pseudoefedrin, antihistamin, dan dextromethorphan.

Badan administrasi pangan dan obat Amerika Serikat (FDA) mengeluarkan rekomendasi, bahwa obat batuk pilek yang dijual bebas tidak boleh diberikan pada anak usia kurang dari 2 tahun. Setelah rekomendasi (2007) tersebut, kunjungan pasien ke unit gawat darurat akibat efek merugikan berkurang menjadi setengahnya. ${ }^{1,3,4}$ Beberapa perusahaan juga telah mengikuti rekomendasi tersebut dengan mengubah label produknya untuk tidak digunakan pada anak usia dibawah 4 tahun. Sedangkan American Academy of Pediatrics (AAP) merekomendasikan untuk tidak menggunakan obat batuk pilek yang dijual bebas pada anak usia di bawah 6 tahun. Dalam perkembangannya, komite FDA juga menyarankan hal yang sama seperti rekomendasi dari AAP untuk tidak menggunakan obat batuk pilek pada anak usia kurang dari 6 tahun. ${ }^{1,2,5}$

Batuk sebagai refleks fisiologis anak, merupakan mekanisme tubuh untuk membersihkan saluran napas dan paru-paru dari mikroorganisme, lendir, dan benda asing. Namun, pemberian obat yang dilakukan oleh orang tua banyak ditujukan untuk menghentikan gejala batuk, kongesti nasal, dan rinorhea. ${ }^{6}$ Setiap minggunya, lebih dari 10\% anak di Amerika Serikat diterapi menggunakan obat batuk pilek OTC, dan sebagian besar sediaan memiliki kombinasi komposisi. Bukti ilmiah terhadap penggunaan obat batuk pilek OTC sangat sedikit, bahkan terdapat bukti peningkatan adanya efek merugikan (adverse events) yang dapat diakibatkan oleh penggunaan obat tersebut. ${ }^{1}$

Beberapa tahun terakhir ini, penggunaan obat batuk pilek untuk bayi dan anak mendapat pengawasan yang ketat. Selama 20 tahun terakhir, 123 kematian terjadi pada anak yang berusia di bawah 6 tahun diakibatkan oleh penggunaan obat batuk pilek OTC. Risiko kecelakaan akibat overdosis/kelebihan dosis dan efek merugikan disebabkan oleh banyak faktor. Pedoman dosis obat batuk pilek anak sampai saat ini belum terstandarisasi. Dosis anak yang ada saat ini diperoleh dari ekstrapolasi dosis dewasa sehingga adanya produk OTC dengan berbagai komposisi kombinasi mempermudah timbulnya overdosis/ kelebihan dosis. Hal tersebut juga diakibatkan karena kurangnya pemahaman/ketidaktahuan orang tua terhadap obat yang diberikan pada anaknya. ${ }^{1}$

Penggunaan obat batuk pilek yang beredar bebas, belum sepenuhnya teruji efektivitasnya pada anak, bahkan terdapat risiko efek samping berbahaya. Tujuan penelitian ini untuk mengetahui profil penggunaan obat batuk pilek yang dijual bebas oleh orang tua pada anak usia di bawah 6 tahun di Puskesmas Kelurahan Pegangsaan, Jakarta.

\section{Metode}

Penelitian deskriptif (survei) untuk mengetahui profil penggunaan obat batuk pilek yang dijual bebas oleh orang tua pada anak usia di bawah 6 tahun di Puskesmas Kelurahan Pegangsaan, Jakarta. Penelitian ini dilakukan pada tanggal 17 Oktober 2011 sampai 04 November 2011. Data diambil dari responden dengan teknik wawancara menggunakan kuesioner. Isi kuesioner meliputi identitas pasien, penyakit batuk pilek yang dialami oleh anak, tindakan orang tua di rumah, dan penggunaan obat batuk pilek yang dijual bebas. Pemilihan sampel dilakukan secara konsekutif dan disajikan dalam bentuk tekstular dan tabular.

\section{Hasil}

Selama periode penelitian diperoleh 106 subyek penelitian yang mengisi lembar kuesioner. Sebagian besar responden adalah perempuan (ibu pasien), dengan tingkat pendidikan umumnya rendah dan menengah, hanya sekitar $11,3 \%$ yang berasal dari tingkat pendidikan tinggi (lulusan akademi/ universitas). Rentang usia anak terbanyak adalah 2-6 tahun $(57,5 \%)$ (Tabel 1$)$.

Untuk mengetahui gambaran penggunaan obat dinilai beberapa hal, yaitu penyakit batuk pilek anak, tindakan yang dilakukan saat anak batuk pilek, dan penggunaan obat batuk pilek itu sendiri. Mengenai penyakit batuk pilek, sebagian besar anak $(89,6 \%)$ mengalami episode sakit 1-3 x dalam 3 bulan terakhir. Gejala terbanyak adalah batuk berdahak $(47,2 \%)$, hidung berair/tersumbat $(47,2 \%)$, demam $(34,9 \%)$, batuk kering $(30,2 \%)$, dan gejala batuk malam hari, tetapi mereda pada siang hari $11,3 \%$ (Tabel 2.). 
Tabel 1. Data dasar $(n=102)$

\begin{tabular}{ll}
\hline Data dasar & $\mathrm{n}(\%)$ \\
\hline Orang tua & \\
Tingkat pendidikan responden & \\
Tidak sekolah & $1(0,9)$ \\
SD & $5(4,7)$ \\
SMP & $25(23,7)$ \\
SMA & $63(59,4)$ \\
D3 & $5(4,7)$ \\
S1 & $6(5,7)$ \\
S2 & $1(0,9)$ \\
Pekerjaan & \\
Ibu rumah tangga & $78(73,6)$ \\
Karyawan & $17(16)$ \\
Buruh & $1(0,9)$ \\
Guru & $1(0,9)$ \\
PNS & $5(4,7)$ \\
Wiraswasta & $4(3,9)$ \\
Anak & \\
Jenis kelamin pasien & \\
Laki-laki & \\
Perempuan & $59(55,7)$ \\
Usia pasien (tahun) & $47(44,3)$ \\
$<1$ & \\
$1-2$ & $23(21,7)$ \\
2-6 & $22(20,8)$ \\
\hline
\end{tabular}

Tabel 2. Gejala batuk pilek

\begin{tabular}{ll}
\hline Anamnesis & $\mathrm{n}(\%)$ \\
\hline Jumlah sakit batuk pilek (3 bulan terakhir) & \\
$1-3 \mathrm{x}$ & $95(89,6)$ \\
$4-5 \mathrm{x}$ & $6(5,7)$ \\
$>5 \mathrm{x}$ & $5(4,7)$ \\
Gejala anak sakit batuk pilek & \\
Kering & $32(30,2)$ \\
Berdahak & $50(47,2)$ \\
Malam hari, mereda siang hari & $12(11,3)$ \\
Hidung berair - tersumbat & $50(47,2)$ \\
Demam & $37(34,9)$ \\
\hline
\end{tabular}

Dari hasil penelitian didapatkan tindakan yang dilakukan oleh orang tua ketika anak mengalami sakit batuk pilek adalah terbanyak memberi obat batuk pilek yang dijual bebas $(82,1 \%)$, memberi obat gosok $(55,7 \%)$, memberi air minum hangat (28,3\%), suplemen vitamin $(14,2 \%)$, dan memberi jamu tradisional $(5,7 \%)$. Hanya $17,9 \%$ orang tua yang langsung membawa anak ke dokter dan terdapat $2,8 \%$ orang tua yang memberikan sendiri antibiotik (Tabel 3).
Tabel 3. Profil penggunaan obat batuk pilek (OTC)

\begin{tabular}{|c|c|}
\hline Penggunaan obat batuk pilek OTC & $\mathrm{n}(\%)$ \\
\hline \multicolumn{2}{|l|}{ Kapan memberikan obat batuk pilek } \\
\hline Tidak sembuh $>3$ hari & $39(44,8)$ \\
\hline Menganggu aktivitas / tidur & $21(24,1)$ \\
\hline Disertai dengan demam & $27(31,1)$ \\
\hline \multicolumn{2}{|l|}{ Alasan memberi obat batuk pilek } \\
\hline Supaya cepat sembuh & $41(47,2)$ \\
\hline Pelayanan kesehatan jauh & $3(3,4)$ \\
\hline Sibuk & $1(1,1)$ \\
\hline Obat saja bisa sembuh & $4(4,7)$ \\
\hline Biaya dokter lebih mahal & $1(1,1)$ \\
\hline Pengobatan sementara & $37(42,5)$ \\
\hline \multicolumn{2}{|l|}{ Dosis (mengikuti aturan pakai) } \\
\hline Ya & $79(90,8)$ \\
\hline Tidak - (tidak bisa baca tulis) & $8(9,2)$ \\
\hline \multicolumn{2}{|l|}{ Lama pemberian obat (hari) } \\
\hline$<3$ & $55(63,2)$ \\
\hline $3-5$ & $25(28,7)$ \\
\hline 5 & $7(8,1)$ \\
\hline \multicolumn{2}{|l|}{ Mengetahui/merasakan efek samping } \\
\hline Ya & $27(31)$ \\
\hline Mengantuk & $22(81,5)$ \\
\hline Mual & $1(3,7)$ \\
\hline Gangguan hati & $1(3,7)$ \\
\hline Gangguan ginjal & $1(3,7)$ \\
\hline Gangguan gigi & $1(3,7)$ \\
\hline Jantung berdebar-debar & $1(3,7)$ \\
\hline Tidak & $60(69)$ \\
\hline \multicolumn{2}{|l|}{ Tindakan bila belum sembuh } \\
\hline Mengganti obat batuk pilek & $2(2,3)$ \\
\hline Membawa ke dokter & $85(97,7)$ \\
\hline \multicolumn{2}{|l|}{ Kapan anak dibawa ke dokter } \\
\hline Tidak sembuh $>3$ hari & $62(71,3)$ \\
\hline Disertai dengan gejala lain & $25(28,7)$ \\
\hline \multicolumn{2}{|l|}{ Informasi obat batuk pilek } \\
\hline Keluarga & $13(14,9)$ \\
\hline Teman/tetangga & $9(10,4)$ \\
\hline Iklan di media & $17(19,5)$ \\
\hline Tenaga medis & $38(43,7)$ \\
\hline Toko/supermarket & $10(11,5)$ \\
\hline
\end{tabular}

Sebagian besar orang tua $(44,8 \%)$ akan memberikan obat batuk pilek bila anak sakit dan belum mengalami perbaikan lebih dari 3 hari, $31,1 \%$ orang tua baru memberikan obat batuk pilek bila anak sakit batuk pilek disertai dengan demam. Adapun alasan terbanyak pemberian obat batuk pilek adalah supaya anak cepat sembuh (47,2\%). Hanya $42,5 \%$ orang tua yang menganggap pemberian obat batuk pilek sebagai pengobatan sementara sebelum membawa anak ke 
dokter. Hampir semua orang tua $(90,8 \%)$ mengikuti instruksi aturan pakai dalam kemasan obat, sedangkan sebagian kecil menggunakan pengalaman pribadi atau perkiraan dosis karena tidak bisa baca tulis. Lama pemberian obat terbanyak selama $1-3$ hari $(63,2 \%)$. Tigapuluh satu persen orang tua yang mengetahui efek samping dari obat batuk pilek yang digunakan, terbanyak adalah gejala mengantuk $(81,5 \%)$. Bila dengan obat batuk pilek yang digunakan, anak belum sembuh maka sebagian besar orang tua $(97,7 \%)$ akan langsung membawa anak ke dokter, sedangkan 2,3\% mencoba mengganti dengan obat batuk pilek merek lain (Tabel 3). Komposisi obat batuk pilek yang terbanyak digunakan adalah klorfeniramin maleat $(58,8 \%)$, parasetamol $(56,5 \%)$, gliceryl guaicolate $(50,6 \%)$, pseudoefedrin $(28,2 \%)$, dextromethorphan $(22,4 \%)$ dan bromhexine (9,4\%). (Tabel 4). Sebagian besar $(43,7 \%)$ sumber informasi merek batuk pilek yang dipilih oleh orang tua adalah berasal dari tenaga medis baik dokter, bidan, maupun perawat.

Tabel 4. Komposisi dari obat batuk pilek (OTC) yang digunakan

\begin{tabular}{lc}
\hline Komposisi & $\mathrm{n}(\%)$ \\
\hline Klorfeniramin maleat & $50(58,8)$ \\
Parasetamol & $48(56,5)$ \\
Gliceryl guaicolate & $43(50,6)$ \\
Pseudoephedrine & $24(28,2)$ \\
Dextromethorphan & $19(22,4)$ \\
Bromhexine & $8(9,4)$ \\
Amonium Cl & $7(8,2)$ \\
Ephedrine & $5(5,9)$ \\
Ambroksol Hcl & $5(5,9)$ \\
Phenylpropanolamine & $2(2,4)$ \\
Diphenhydramine & $2(2,4)$ \\
Salisilamid & $2(2,4)$ \\
Ibuprofen & $1(1,2)$ \\
Salbutamol & $1(1,2)$ \\
Phenylefrin & $1(1,2)$ \\
Triprolidin & $1(1,2)$ \\
Teofilin & $1(1,2)$ \\
\hline
\end{tabular}

\section{Pembahasan}

Batuk pilek merupakan salah satu penyakit tersering yang dialami oleh anak. ${ }^{78}$ Hasil tersebut sebanding dengan hasil penelitian kami, $100 \%$ anak pernah mengalami episode sakit batuk pilek selama 3 bulan terakhir, 89,6\% di antaranya mengalami episode sakit 1-3x, insiden yang sama juga ditemukan di Amerika Serikat, terdapat kejadian batuk pilek pada anak di bawah usia 6 tahun sebesar $6-8 \mathrm{x}$ per tahun. ${ }^{1,9}$

Gejala terbanyak dialami anak yang diberi obat batuk pilek adalah batuk berdahak $(47,2 \%)$, hidung berair/tersumbat $(47,2 \%)$, demam $(34,9 \%)$, batuk kering $(30,2 \%)$. Kami menemukan gejala batuk sedikit lebih tinggi 30\% dibandingkan dengan literatur, ${ }^{9}$ perbedaan tersebut disebabkan oleh banyak faktor di antaranya pengaruh iklim dan lingkungan. Terdapat $11,3 \%$ anak mengalami gejala batuk terutama pada malam hari dan mereda pada siang hari, yang mungkin dapat mengarahkan ke rinitis alergik tetapi kami tidak menelusuri lebih lanjut. Mengenai tindakan yang dilakukan oleh orang tua di rumah, 28,3\% memberi banyak minum air hangat. Banyak minum atau hidrasi dan inhalasi uap air hangat merupakan salah satu tindakan yang bermanfaat untuk mengurangi gejala kongesti nasal. ${ }^{6}$ Sebanyak $55,7 \%$ orang tua memberikan obat gosok di tubuh anak. Pada salah satu studi yang dilakukan di Amerika Serikat, penggunaan obat gosok terbukti dapat meringankan gejala batuk malam, hidung tersumbat, dan kesulitan tidur. ${ }^{1,10}$

Sebanyak $2,8 \%$ orang tua masih memberikan antibiotik sendiri, bahkan terdapat 2 responden yang menyatakan bahwa antibiotik merupakan bagian dari obat batuk pilek. Penyebab terbanyak rhinitis adalah rhinovirus (50\%), dan sisanya disebabkan oleh jenis virus lain seperti adenovirus, influenza, enterovirus, RSV dan coronavirus. ${ }^{1}$ Suatu review sistematik menyatakan bahwa penggunaan antibiotik tidak memiliki peranan dalam terapi rhinitis. Hal tersebut disebabkan karena antibiotik terbukti tidak efektif dalam mengurangi lama gejala, tingkat keparahan, serta kemungkinan timbulnya risiko efek samping gastrointestinal dan resistensi kuman. Oleh karena itu, penggunaannya tidak direkomendasikan baik pada anak maupun dewasa. ${ }^{6,11,12}$

Empatbelas koma dua persen orang tua memberikan suplemen vitamin bila anak sakit batuk pilek. Suatu studi dalam Cochrane review menunjukkan bahwa konsumsi vitamin $\mathrm{C}$ setiap hari tidak secara signifikan mencegah timbulnya penyakit batuk pilek. Kesimpulan penelitian yang sama juga ditemukan pada penggunaan echinaceae dalam terapi rhinitis. ${ }^{13-16}$

Lima koma tujuh persen orang tua memberikan jamu tradisional seperti tolak angin anak, jeruk nipis dan kecap, serta beras kencur. Kandungan dalam 
tolak angin anak adalah berbagai ekstrak tanaman herbal (Foeniculli Fructus, Isorae Fructus, Caryophylli Folium), jahe, dan madu. Dalam studi tahun 2010 yang dilakukan pada hewan percobaan, pemberian tolak angin cair dapat meningkatkan kadar antibodi interferon gamma. ${ }^{17}$ Kandungan madu sendiri terbukti dapat mengurangi gejala batuk dan memperbaiki kualitas tidur anak pada malam hari. ${ }^{18}$ Jeruk nipis bisa dipakai sebagai komponen obat batuk herbal. Menurut Sumali ${ }^{19}$ dari Pusat Studi Obat Bahan Alam Departemen Farmasi Universitas Indonesia, jeruk nipis (Citrus aurantifolia) mengandung minyak atsiri dan zat-zat yang mampu meredakan gejala batuk. Selain sebagai obat batuk, buah jeruk nipis juga berkhasiat sebagai obat penurun panas, menambah nafsu makan, mengatasi suara serak. Penambahan kecap pada air jeruk nipis, dimaksudkan untuk mengurangi keasaman air jeruk, sehingga air jeruk nipis bisa dikonsumsi. Komponen yang sama berupa minyak atsiri juga ditemukan dalam beras kencur, sehingga beras kencur juga dapat digunakan meredakan gejala batuk. ${ }^{20}$ Dalam suatu review terhadap beberapa complimentary medicines yang banyak digunakan untuk terapi penyakit batuk pilek disimpulkan bahwa madu mungkin mempunyai manfaat, sedangkan studi pada echinacea, probiotik, vitamin C, dan Zinc sampai saat ini masih belum dapat disimpulkan karena jumlah penelitian masih sangat terbatas, sehingga penelitian tambahan diperlukan sebelum rekomendasi definitif dibuat. ${ }^{21}$ Tujuhbelas koma sembilan persen orang tua langsung membawa anaknya ke dokter, dengan alasan kekhawatiran akan efek samping penggunaan obatobat batuk pilek yang dijual bebas.

Dari hasil penelitian kami, sebagian besar orang tua $(82,1 \%)$ masih memberikan obat batuk pilek pada anaknya. Hal tersebut bertentangan dengan rekomendasi yang telah dikeluarkan oleh FDA dan AAP. American Academy of Pediatrics (AAP) menyatakan bahwa obat - obat batuk pilek OTC pada umumnya tidak efektif dan berisiko memicu efek sampingan serius bagi anak. Pada suatu studi penggunaan obat batuk pilek pada anak dibawah 1 tahun, ditunjukkan adanya hubungan antara kejadian sudden infant death dengan penggunaan obat batuk pilek yang mengandung pseudoefedrin, antihistamin, dan dextromethorphan. ${ }^{2}$ Hasil penelitian kami menunjukkan bahwa obat batuk pilek terbanyak digunakan adalah obat batuk pilek kombinasi dengan komposisi utama meliputi klorfeniramin maleat
$(58,8 \%)$, parasetamol $(56,5 \%)$, gliceryl guaicolate $(50,6 \%)$, pseudoefedrin $(28,2 \%)$, dextromethorphan $(22,4 \%)$ dan bromhexine $(9,4 \%)$.

Klorfeniramin maleat dan dyphenhydramine adalah antihistamin generasi satu. Penggunaan terhadap orang dewasa, antihistamin terbukti dapat mengurangi gejala bersin dan memperbaiki aliran mukosiliar, namun hal tersebut belum terbukti penggunaannya pada anak. Suatu studi yang menilai efektivitas kombinasi antihistamin dan dekongestan, menunjukkan tidak ada perbaikan gejala batuk dibandingkan dengan plasebo. Salah satu efek samping dari kombinasi tersebut adalah memperkental sekresi mukus, sehingga merugikan terutama pada pasien bronkitis. ${ }^{22}$ Ekspektoran berguna untuk meningkatkan produksi mukus. Gliceryl guaicolate adalah salah satu jenis ekspektoran yang paling banyak digunakan. Pada orang dewasa, penggunaan ekspektoran dapat mengurangi frekuensi batuk, tetapi belum terbukti efektivitasnya pada anak. ${ }^{1}$ Pseudoefedrin, phenylpropanolamine, dan phenylefrin berfungsi sebagai dekongestan/vasokonstriktor, bekerja melalui reseptor adrenergik. Pada suatu studi, kombinasi dekongestan dan antihistamin tidak terbukti memperbaiki gejala kongesti nasal, rhinorrhea, dan batuk dibandingkan dengan plasebo. ${ }^{23}$

Batuk sebagai refleks fisiologis anak merupakan salah satu mekanisme tubuh untuk membersihkan saluran napas dan paru-paru. Penekanan refleks batuk mungkin dapat memiliki efek yang berbahaya. ${ }^{1}$ Dextromethorphan merupakan antitusif yang bekerja secara sentral, menekan pusat batuk di susunan saraf pusat. Hasil dari dua studi menunjukkan tidak ada perbaikan gejala batuk pada penggunaan dextromethorphan dibandingkan dengan placebo. ${ }^{24,25}$ Berbagai jenis mukolitik seperti ambroksol dan acetylcystein, bekerja dengan cara mengurangi viskositas cairan sehingga mukus menjadi lebih encer dan mudah untuk dikeluarkan. Sekarang ini, mukolitik sebagai obat batuk anak cukup banyak dipakai. Mukolitik diberikan pada anak dengan kesadaran dan refleks batuk yang baik sehingga anak mampu mengeluarkan mukus tersebut. Suatu penelitian penggunaan mukolitik pada anak dibawah 1 tahun, ditunjukkan adanya risiko berbahaya yaitu kongesti bronkial paradoksikal. ${ }^{26}$

Acetaminophen / parasetamol sebagai antipiretik, relatif aman untuk digunakan pada anak. Pada penelitian kami, parasetamol digunakan dalam 
kombinasi terhadap obat batuk pilek lain, hanya $10,6 \%$ antipiretik yang digunakan secara tunggal untuk menurunkan gejala demam, sisanya antipiretik digunakan dalam kombinasi dengan jenis obat lain. Hal tersebut tentu berlebihan karena tidak semua anak dengan batuk pilek mengalami gejala demam, dalam survei kuesioner yang dilakukan hanya 34,9\% gejala demam yang dialami oleh anak.

Dalam MIMS edisi ke-118 tahun 2011, terdapat 132 merek obat batuk pilek yang dijual bebas (kode B dan W) di Indonesia, dengan kombinasi terbanyak ditemukan adalah enam komposisi. Komposisi utama tersebut adalah klorfeniramin maleat $45 \%$, dextromethorphan 39\%, parasetamol 37\%, gliceryl guaicolate $31 \%$, phenylpropanolamine $31 \%$, diphenhydramine 23\%. Dari 132 merek terdapat 16 merek obat yang masih mencantumkan indikasi penggunaaan untuk anak di bawah 2 tahun, dengan komposisi $31,3 \%$ obat mengandung dextromethorphan dan 25\% bromhexine. Dibandingkan dengan dosis dalam textbook Nelson of Pediatric edisi 18, beberapa dosis obat seperti parasetamol berada pada rentang dosis standar. Dosis klorfeniramin maleat, gliceryl guaicolate dan pseudoefedrin cenderung berada lebih rendah dari dosis minimal. Sedangkan untuk dosis dextromethorphan berada pada dosis normal sampai melebihi dosis maksimal. Badan Pengawas Obat dan Makanan (BPOM) belum membuat aturan khusus tentang penggunaan obat batuk pilek OTC di Indonesia. BPOM hanya menyarankan untuk mengkonsumsi obat flu dan batuk sesuai dosis, tidak boleh melebihi yang tercantum di dalam aturan pakai bagi anak dan dewasa. Selama ini, dengan dosis tersebut BPOM belum menemukan laporan efek samping yang berbahaya. Sedangkan peringatan kepada pasien tertentu sudah tercantum pada masing-masing kemasan obat. ${ }^{27}$

Penanganan penyakit batuk pilek pada anak saat ini yang aman hanya tindakan suportif berupa hidrasi dan nasal saline. Penggunaan obat batuk pilek yang beredar bebas, belum sepenuhnya teruji efektivitasnya pada anak, bahkan terdapat risiko efek samping berbahaya yang dapat ditimbulkan seperti sudden infant death. Pemilihan jenis obat harus dilakukan oleh dokter dengan mempertimbangkan antara manfaat dan risiko yang mungkin terjadi. Berdasarkan rekomendasi FDA dan AAP, maka perlu didiskusikan kembali standar komposisi obat batuk pilek yang dijual bebas terutama untuk anak usia dibawah 6 tahun. ${ }^{1,2,5}$

\section{Kesimpulan}

Sebanyak $82,1 \%$ orang tua memberikan obat batuk pilek OTC bila anaknya sakit batuk pilek. Komposisi kombinasi obat OTC yang banyak digunakan adalah klorfeniramin maleat $(58,8 \%)$, parasetamol $(56,5 \%)$, gliceryl guaicolate $(50,6 \%)$, pseudoefedrin $(28,2 \%)$, dextromethorphan $(22,4 \%)$ dan bromhexine $(9,4 \%)$. Pemberian obat OTC yang mengandung antitusif, antihistamin, dekongestan, dan ekspektoran belum terbukti efektivitasnya pada anak, dan efek samping mengantuk yang terbanyak dirasakan.

\section{Saran}

Badan pengawasan obat dan makanan (BPOM) perlu menetapkan secara lebih rinci standar komposisi obat - obat batuk pilek yang dijual bebas, mengacu pada rekomendasi AAP dan FDA. Dextromethorphan dan phenylpropanolamine sebaiknya tidak diberikan untuk anak usia dibawah 6 tahun. Hati-hati pemberian obat OTC yang mengandung pseudoefedrin dan antihistamin pada anak usia dibawah 1 tahun. Hati-hati penggunaan mukolitik untuk anak usia dibawah 1 tahun. Edukasi kepada masyarakat untuk melakukan penanganan sementara batuk pilek dengan hidrasi. Edukasi kepada orang tua pasien tentang penggunaan obat batuk pilek OTC dan risiko efek samping yang dapat timbul.

\section{Daftar pustaka}

1. Diane EP, Owen H. The common cold and decongestant therapy. Pediatrics in Review 2011;32:47-55.

2. Mary ER, Susan N. Unexpected infant deaths associated with use of cough and cold medications. Pediatrics 2008;122:e318-22.

3. Shehab N, Schaefer MK, Kegler SR, Budnitz DS. Adverse events from cough and cold medications after a market withdrawal of products labeled for infants. Pediatrics 2010;126:1100-07.

4. Schaefer MK, Shehab N, Cohen AL, Budnitz DS. Adverse events from cough and cold medications in children. Pediatrics 2008;121:783-7

5. American Academy of Pediatrics Urges Caution in Use of Over-The-counter Cough and Cold Medicines [press release].2008. Didapat dari: http://www.aap.org/advocacy/ releases/jan08coughandcold.htm. (Diakses November 
2010)

6. Madeline S, David AB. Treatment of the common cold. American Academy of Family Physician 2007;75:501520.

7. Sastroasmoro S, Bondan H, Kampono Nl. Panduan pelayanan medis Departemen ILmu Kesehatan Anak RSCM. FKUI; 2007.

8. Pudjiadi AH, Hegar B, Handryastuti S. Pedoman pelayanan medis Ikatan Dokter Anak Indonesia. Pengurus Pusat Ikatan Dokter Anak Indonesia; 2010.

9. Kliegman RM, Behrman RE, Jenson HB, Stanton BF. Nelson Textbook of pediatrics. Edisi ke-18. Philadelphia: Saunders Elsevier; 2008.

10. Paul IM, Beiler JS, King TS, et al. Vapor rub, petrolatum, and no treatment for children with nocturnal cough and cold symptoms. Pediatrics 2010;126:1092-9.

11. Kliegman RM, Behrman RE, Jenson HB, Stanton BF. Nelson Textbook of pediatrics. Edisi ke-18. Philadelphia: Saunders Elsevier; 2008.

12. Paul IM, Beiler JS, King TS. Vapor rub, petrolatum, and no treatment for children with nocturnal cough and cold symptoms. Pediatrics 2010;126:1092-9.

13. Turner RB, Bauer R, Woelkart K. An evaluation of Echinacea angustifolia in experimental rhinovirus infection. N Engl J Med 2005;353:341-8.

14. Linde K, Barrett B, Wolkart K. Echinacea for preventing and treating the common cold. Cochrane Database Syst Rev 2006;CD000530.

15. Douglas RM, Hemila H, D'Souza R. Vitamin C for preventing and treating the common cold. Cochrane Database Syst Rev 2004;CD000980.

16. Kliegman RM, Behrman RE, Jenson HB, Stanton BF. Nelson Textbook of pediatrics. Edisi ke-18. Philadelphia: Saunders Elsevier; 2008.

17. Paul IM, Beiler JS, King TS, et al. Vapor rub, petrolatum, and no treatment for children with nocturnal cough and cold symptoms. Pediatrics 2010;126:1092-9.

18. Paul MD, Beller J, McMonagle A. Effect of honey, dextromethorphan, and no treatment on nocturnal cough and sleep quality for coughing children and their parents. Arch Pediatr Adolesc Med 2007;191:1140-6.

19. Benarkah jeruk nipis dan kecap sembuhkan batuk?. Didapat dari: http://www.health.kompas.com. (Diakses 15 November 2011).

20. Kencur, Tanaman yang banyak khasiatnya. Didapat dari: http://erabaru.net. (Diakses 15 November 2011).

21. Cecilia B, Christopher L, Sunita V. Complementary, Holistic, and Integrative Medicine : The Common Cold. Pediatrics in Rev 2008;29;e66.

22. Smith SM, Schroeder K, Fahey T. Over-the-counter medications for acute cough in children and adults in ambulatory settings. Cochrane Database Syst Rev 2008; 1:CD001831.

23. Clemens CJ, Taylor JA, Almquist JR, Quinn HC. Is an antihistamine-decongestant combination effective in temporarily relieving symptoms of the common cold in preschool children?. J Pediatr 1997;464-6.

24. Taylor JA, Novack AH, Almquist JR, Rogers JE. Efficacy of cough suppressants in children. J Pediatr 1993;122:799-802.

25. Paul IM, Shaffer ML, Yoder KE, Sturgis SA. Dose response relationship with increasing doses of dextromethorphan for children with cough. Clin Ther 2004;26:1508-14.

26. Chalumeau M, Chéron G. Mucolytic agents for acute respiratory tract infections in infants: a pharmacoepidemiologic problem?. Arch Pediatr 2002;9:1128-36.

27. Pengobatan untuk batuk pilek umumnya tidak efektif. Didapat dari: http://batukpilek.com/pengobatan-untuk-batukpilek-umumnya-tidak-efektif.html. (Diakses 25 November 2011). 